\author{
Marquette University \\ e-Publications@Marquette
}

College of Nursing Faculty Research and

Publications

Nursing, College of

$11-2015$

\title{
The Relationship of Anti-Mullerian Hormone Levels and Urine Cortisol in Women with Chronic Abdominal Pain
}

Theresa Hardy

Marquette University

Donna O. McCarthy

Marquette University, donnalee.mccarthy@marquette.edu

Nicolaas Fourie

National Institutes of Health

Wendy Henderson

National Institutes of Health

Follow this and additional works at: https://epublications.marquette.edu/nursing_fac

Part of the Nursing Commons

\section{Recommended Citation}

Hardy, Theresa; McCarthy, Donna O.; Fourie, Nicolaas; and Henderson, Wendy, "The Relationship of AntiMullerian Hormone Levels and Urine Cortisol in Women with Chronic Abdominal Pain" (2015). College of Nursing Faculty Research and Publications. 405.

https://epublications.marquette.edu/nursing_fac/405 


\title{
The Relationship of Anti-Mullerian Hormone Levels and Urine Cortisol in Women with Chronic Abdominal Pain
}

\author{
Theresa Hardy \\ College of Nursing, Marquette University \\ Milwaukee, WI \\ Donnalee McCarthy \\ College of Nursing, Marquette University \\ Milwaukee, WI \\ Nicolaas Fourie \\ National Institutes of Health, \\ Bethesda, MD \\ Wendy Henderson \\ National Institutes of Health, \\ Bethesda, MD
}

Context: Persistent and intense stress leads to chronic activation of the hypothalamic-pituitary-adrenal (HPA) axis, placing an individual at 
NOT THE PUBLISHED VERSION; this is the author's final, peer-reviewed manuscript. The published version may be accessed by following the link in the citation at the bottom of the page.

increased risk for the development of disease. HPA activity inhibits ovarian functioning, and may contribute to female infertility.

Objective: The objective of the study was to explore the association of HPA activity with ovarian functioning in female participants with and without chronic abdominal pain (CAP).

Design/setting/and subjects: A secondary data analysis was performed using data from female participants in a natural history protocol at the National Institutes of Health. A total of 36 females (1939 years, mean 27.11 ) were included in the study.

Main outcome measurements: Whole blood was drawn for determination of serum levels of anti-Mullerian hormone $(\mathrm{AMH})$, luteinizing hormone, follicle stimulating hormone, and cortisol. Urine samples were collected over a five hour period for determination of cortisol levels. CAP was defined as presence or absence of chronic abdominal pain for $>6$ months and was determined via self-report.

Results: AMH concentrations declined significantly with age as expected. When AMH levels were dichotomized as normal or abnormal (defined as higher or lower than age-specific normative ranges), there were significant associations between abnormal AMH levels and CAP and urine cortisol levels. Subjects with CAP or low urine cortisol levels were significantly more likely to have abnormal AMH levels.

Conclusions: Results suggest that chronic pain and HPA dysregulation may be associated with abnormal AMH levels.

[Citation Journal/Monograph Title, Vol XX, No. XX (m yyyy): pg. XX-XX. DOI. This article is @ [Publisher's Name] and permission has been granted for this version to appear in e-Publications@Marquette. [Publisher's Name] does not grant permission for this article to be further copied/distributed or hosted elsewhere without the express permission from [Publisher's Name].] 